\title{
Czynnik transkrypcyjny ChREBP - koordynator metabolizmu węglowodanów i lipidów
}

\section{Joanna Krawczak,}

\section{mgr Aleksandra Owczarek,}

\section{dr hab. Katarzyna Winiarska}

Zakład Regulacji Metabolizmu, Instytut Biochemii, Wydział Biologii, Uniwersytet Warszawski

https://doi.org/10.18388/pb.2019_282

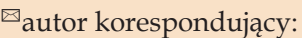

k.winiarska@biol.uw.edu.pl

Słowa kluczowe: ChREBP, czynnik transkrypcyjny, metabolizm węglowodanów, metabolizm lipidów, choroba metaboliczna

Wykaz skrótów: bHLH/LZ - domena o budowie helisa-pętla-helisa/suwak leucynowy; ChoRE - sekwencja odpowiedzi na węglowodany; ChREBP - białko wiążące sekwencję odpowiedzi na węglowodany; GRACE - zachowana w ewolucji sekwencja aktywująca w odpowiedzi na glukozę; GSM - moduł wrażliwy na glukozę; LID - domena hamująca w odpowiedzi na niskie stężenie glukozy

Podziękowania: Pracę sfinansowano ze środków pochodzących z grantu Narodowego Centrum Nauki nr 2016/21/B/NZ3/00365.

\section{STRESZCZENIE}

Cyynnik transkrypcyjny ChREBP, w kompleksie z białkiem MLX, wiąże się do sekwencji odpowiedzi na węglowodany (ChoRE) obecnej w promotorach genów związanych z glikoliza, glukoneogeneza, szlakiem pentozofosforanowym i lipogeneza, aktywując ich transkrypcję po stymulacji glukozą, niezależnie od insuliny. W pracy szczegółowo omówiono mechanizmy regulacji ChREBP, jego fizjologiczne funkcje i implikacje w patofizjologii; zwrócono także uwagę na możliwość zastosowania modulacji aktywności ChREBP w terapii m.in. niealkoholowego stłuszczenia wątroby, cukrzycy typu 2 i chorób nowotworowych.

\section{WPROWADZENIE}

Glukoza służy nie tylko jako substrat energetyczny, ale także jako prekursor do syntezy związków zapasowych i cząsteczka sygnałowa. Wątroba utrzymuje stężenie glukozy we krwi na stałym poziomie, przetwarzając jej nadwyżki w kwasy tłuszczowe i glikogen. Aby wydajnie zarządzać zapasem energetycznym, w organizmach ssaków wyewoluowały różne mechanizmy regulujące jego powstawanie. W wątrobie i tkance tłuszczowej nadmiar glukozy stymuluje ekspresję genów glikolitycznych i lipogenicznych niezależnie od insuliny. Geny te zawierają w swoich promotorach sekwencję ChoRE, do której przyłącza się pośrednik aktywacji transkrypcji przez glukozę: białko wiążące sekwencję odpowiedzi na węglowodany (ChREBP) [1].

ChREBP, czynnik transkrypcyjny z rodziny Mondo, został odkryty przez zespół Uyeda w 2001 roku [1]. Wcześniej rozpoznano chorobę, zespół Williamsa-Beurena, w której występuje delecja genu kodującego ChREBP jako jednego z siedemnastu brakujących genów [2]. Ekspresja genu kodującego ChREBP zachodzi głównie w tkankach aktywnych lipogenicznie, takich jak wątroba czy tkanka tłuszczowa [1]. W związku ze wzrastającą częstotliwością występowania otyłości i chorób metabolicznych, takich jak insulinooporność, cukrzyca typu 2 czy stłuszczenie wątroby, ChREBP jest intensywnie badany jako potencjalny cel w terapii. Wykazano bowiem, że zahamowanie, w wyniku dysrupcji, ekspresji genu Chrebp u myszy ob/ob (zwierzęcy model otyłości charakteryzujący się mutacją w genie kodującym leptynę) korzystnie wpływa na metabolizm lipidów i węglowodanów oraz zmniejsza powikłania zespołu metabolicznego, takie jak otyłość, stłuszczenie wątroby i nietolerancja glukozy [3].

\section{BUDOWA I IZOFORMY - ChREBP-a I ChREBP- $\beta$}

ChREBP, należący do rodziny czynników transkrypcyjnych posiadających domenę o budowie helisa-pętla-helisa/suwak leucynowy (bHLH/LZ) [1], jest aktywny w wątrobie, w jelicie, w tkance tłuszczowej i mięśniowej, w komórkach $\beta$ trzustki oraz w nerkach [4,5]. ChREBP, zwany również MLXIPL, tworzy regulowany przez glukozę kompleks transkrypcyjny z MLX, białkiem z rodziny bHLH/LZ Myc/Max [6]. Heterodimer ChREBP/MLX wiąże się do sekwencji odpowiedzi na węglowodany - ChoRE (CAYGYCnnnnnCRCRTG [7]) w promotorach genów glikolizy, glukoneogenezy i lipogenezy, aktywując ich ekspresję [5]. Okres półtrwania ChREBP wynosi około 30 minut, następnie białko to jest ubikwitynowane i prawdopodobnie podlega degradacji w proteasomie [8].

Dotąd poznano dziewięć izoform ChREBP (https://www.uniprot.org/uniprot/Q9NP71). W 2012 roku zespół Hermana zidentyfikował dwie szczególnie istotne izoformy ChREBP: ChREBP-a i ChREBP- $\beta$, które różnią się lokalizacją wewnątrzkomórkową, aktywnością transkrypcyjną, strukturą białka oraz specyficznymi regulatorami [9]. 


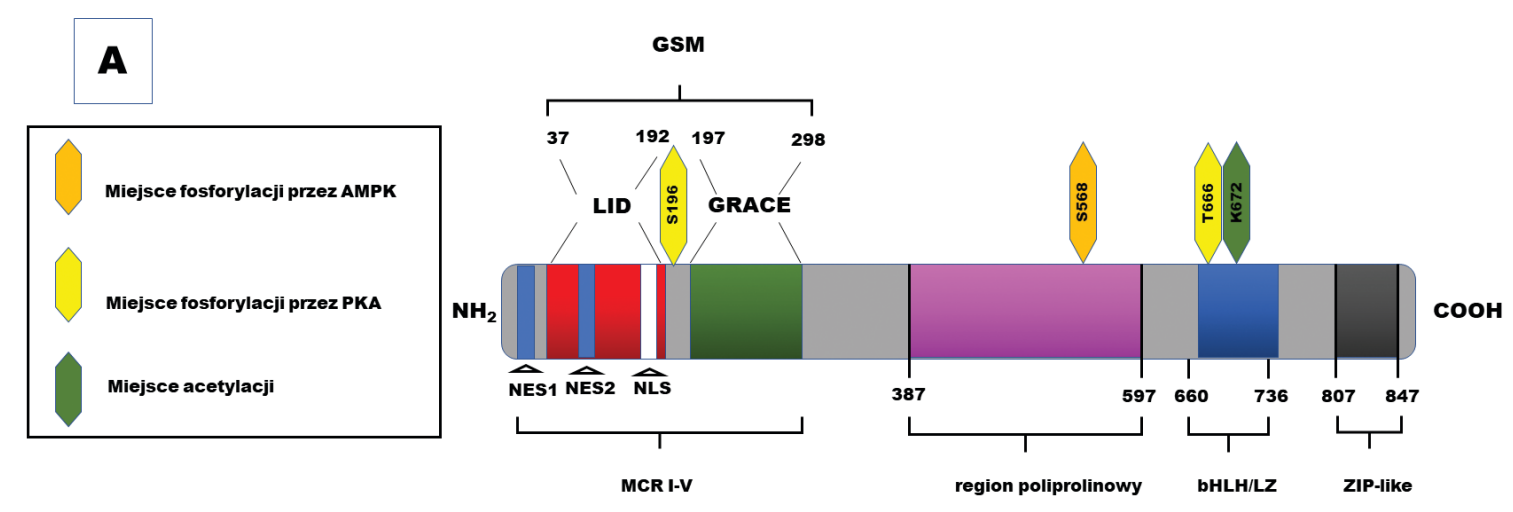

B

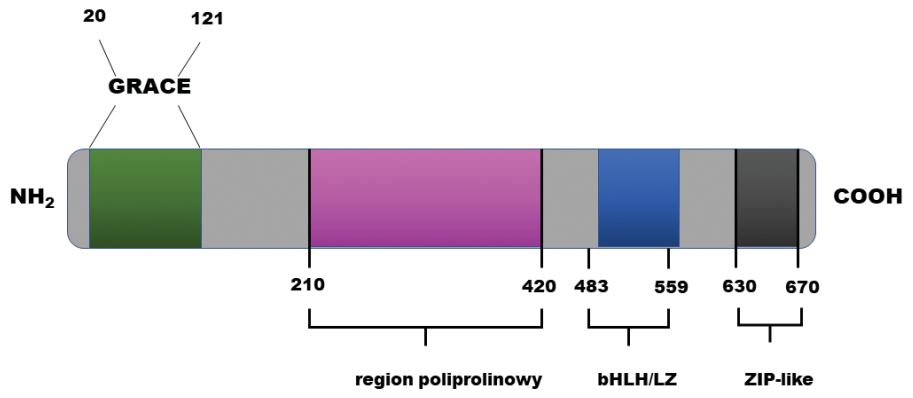

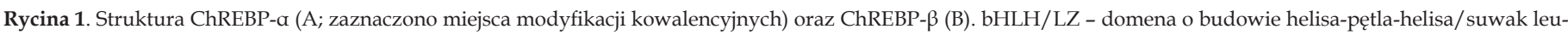

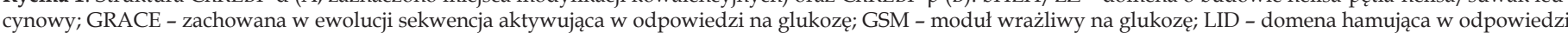

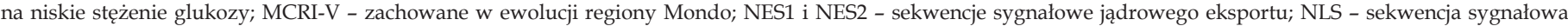
jądrowego importu; ZIP-like - domena podobna do motywu suwaka leucynowego. Na podstawie [10,11].

ChREBP-a (Ryc.1) ma masę cząsteczkową około 95 kDa (864 aminokwasów), składa się z kilku domen funkcjonalnych. Przy N-końcu białka ChREBP-a (1-250 aa) znajdują się dwie sekwencje sygnałowe jądrowego eksportu (NES1 i NES2) oraz sekwencja sygnałowa jądrowego importu (NLS). Domena C-końcowa zawiera motywy wiążące DNA: helisa-pętla-helisa i suwak leucynowy, które umożliwiają aktywność transkrypcyjną ChREBP poprzez heterodimeryzację z MLX. Pomiędzy domenami N- i C-końcową występuje region poliprolinowy [6]. ChREBP-a jest zlokalizowany głownie w cytozolu, jednak w czasie stymulacji glukozą jest transportowany do jądra. Receptory transportu jądrowego (białka 14-3-3, eksportyna I i importyny) w odpowiedzi na zmiany stężenia glukozy wiążą się z NES1, NES2, NLS w sekwencji ChREBP-a, determinując jego lokalizację wewnątrzkomórkową - jądrową lub cytoplazmatyczną $[12,13]$.

Analiza strukturalno-funkcjonalna ChREBP-a, mająca na celu identyfikację regionów odpowiedzi na zmiany stężenia glukozy, doprowadziła do odkrycia na N-końcu białka zachowanej w ewolucji domeny, charakterystycznej dla białek Mondo, którą nazwano modułem wrażliwości na glukozę (GSM) [14]. Moduł ten, znany również jako zachowane w ewolucji regiony Mondo (MCRI-V), składa się z domeny hamującej w odpowiedzi na niskie stężenie glukozy (LID), która obejmuje MCRI-IV, oraz domeny transaktywującej, nazwanej zachowaną $\mathrm{w}$ ewolucji sekwencją aktywującą $\mathrm{w}$ odpowiedzi na glukozę (GRACE), która zawiera MCRV. Zgodnie z modelem LID/GRACE, odpowiedź ChREBP-a na glukozę jest zależna od dynamicznej wewnątrzcząsteczkowej inhibicji pomiędzy LID i GRACE, w której niskie stężenie glukozy hamuje aktywność transkrypcyjną GRACE poprzez LID, zaś wysokie stężenie glukozy znosi tę inhibicję [15].

W pracy Daviesa i wsp. [16] zasugerowano inhibitorowy efekt submodułów MCRI-IV na MCRV w niskich stężeniach glukozy, który mógłby zmieniać konformację ChREBP na nieaktywną. Wzmożony metabolizm glukozy w warunkach hiperglikemii mógłby aktywować ChREBP poprzez zniesienie efektu wewnątrzcząsteczkowej represji, prawdopodobnie poprzez bezpośrednie związanie metabolitu glukozy z regionem MCRVI, ulokowanym pomiędzy MCRIV i MCRV, lub za pomocą koregulatorowych białek [17].

ChREBP- $\beta$ (Ryc.1) ma masę cząsteczkową ok. 72 kDa. Transkrypcja Chrebp $\beta$ znajduje pod kontrolą alternatywnego promotora zlokalizowanego $\mathrm{w}$ górę od eksonu 1a (w eksonie 1b) genu Chrebp. Splicing transkryptu Chrebp $\beta$ zachodzi od eksonu $1 \mathrm{~b}$ do eksonu 2, co skutkuje przesunięciem miejsca startu translacji do eksonu 4 i kończy się syntezą krótszego białka (687 aminokwasów) [9]. Chrebp $\beta$ wykazuje niższą ekspresję niż Chrebpa w wątrobie, białej tkance tłuszczowej i komórkach $\beta$ trzustki [18]. Podobnie jak ChREBP-a, ChREBP- $\beta$ składa się z kilku domen funkcjonalnych, jednak jest pozbawiony domeny LID, co sprawia, że ma dwudziestokrotnie większą aktywność transkrypcyjną niż ChREBP- $a$, niezależnie od stężenia glukozy [9]. Co więcej, ChREBP- $\beta$ nie posiada też domeny NES1 [19]. 


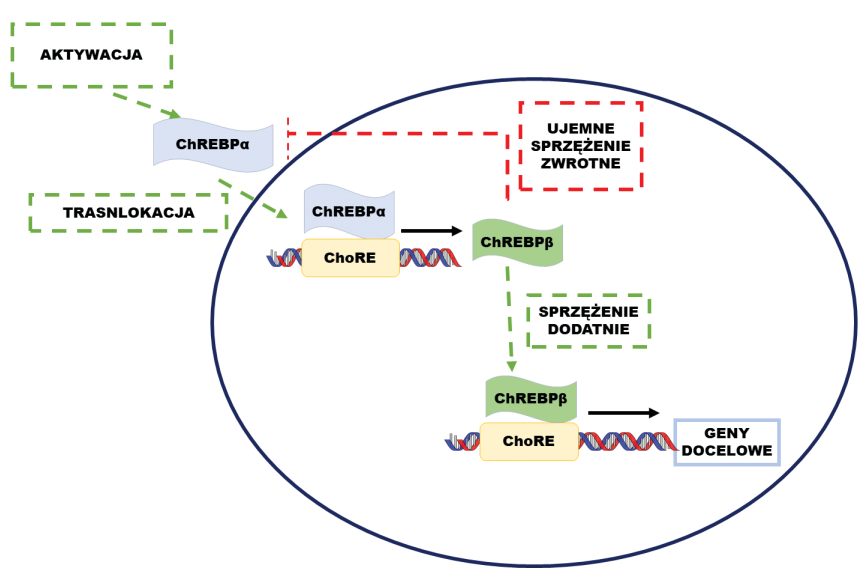

Rycina 2. Wzajemna regulacja pomiędzy izoformami ChREBP. Opis w tekście. Na podstawie [23].

ChREBP- $\beta$ jest stale zlokalizowany w jądrze. ChREBP-a, stymulowany przez produkty metabolizmu glukozy, jest transportowany do jądra, gdzie indukuje ekspresję Chrebp $\beta$ poprzez region ChoRE zidentyfikowany w eksonie $1 \mathrm{~b}$ genu kodującego ChREBP, wzmacniając odpowiedź na glukozę [9]. Jednak regulacja transkrypcji Chrebp $\beta$ wydaje się zależeć także od czynników niezależnych od ChREBP-a, gdyż jego ekspresja w wątrobie wykazuje wyraźny rytm okołodobowy w porównaniu do izoformy a [20].

Niedawne badania dowiodły, że w komórkach $\beta$ trzustki ChREBP- $\beta$, pierwotnie pobudzony przez ChREBP- $\alpha$, może zahamować ekspresję Chrebpa poprzez ujemne sprzężenie zwrotne, co sugeruje wzajemną regulację pomiędzy dwiema izoformami [21] (Ryc. 2). Ponadto, badania dowodzą, że ekspresja Chrebp $\beta$ jest najlepszym odwzorowaniem całkowitej aktywności lipogenicznej ChREBP w białej tkance tłuszczowej i w wątrobie [9]. ChREBP- $\beta$ jest prawdopodobnie bardziej podatny na degradację niż ChREBP-a, o czym może świadczyć utrudniona detekcja tego białka, nawet w warunkach nadekspresji [22].

\section{REGULACJA AKTYWNOŚCI ChREBP}

Aktywność ChREBP jest regulowana w zależności od stężenia glukozy w komórce (Ryc. 3). Mechanizmy, które aktywują ChREBP-a, sprawiają, że jest on transportowany do jądra i wiąże się do sekwencji ChoRE docelowych promotorów, w tym do promotora Chebp $\beta$, aktywując je. Głównym mechanizmem regulacji ChREBP-a są reakcje przyłączania lub odłączania grup fosforanowych [1]. Reakcje fosforylacji inaktywują ChREBP, gdy poziom glukozy w komórce jest niski, a reakcje defosforylacji aktywują ChREBP i promują import jądrowy w warunkach wysokiego stężenia glukozy [24].

ChREBP ma kilka stałych miejsc fosforylacji [23] (Ryc.1). W warunkach niskiego stężenia glukozy, zależna od cAMP, kinaza białkowa A (PKA) fosforyluje ChREBP na reszcie seryny w pozycji 196 (Ser196), co skutkuje zatrzymaniem importu jądrowego, oraz na reszcie treoniny w pozycji 666 (Thr666), co objawia się niezdolnością ChREBP do wiązania się do DNA [23]. Ponadto, ChREBP jest specyficznie fosforylowany poprzez kinazę białkową zależną od AMP (AMPK) na reszcie seryny w pozycji 568 (Ser568), co również uniemożliwia wiązania się ChREBP do DNA [25].

Niska dostępność glukozy powoduje włączenie określonych szlaków sygnałowych, które informują komórkę o braku podstawowego substratu energetycznego - o

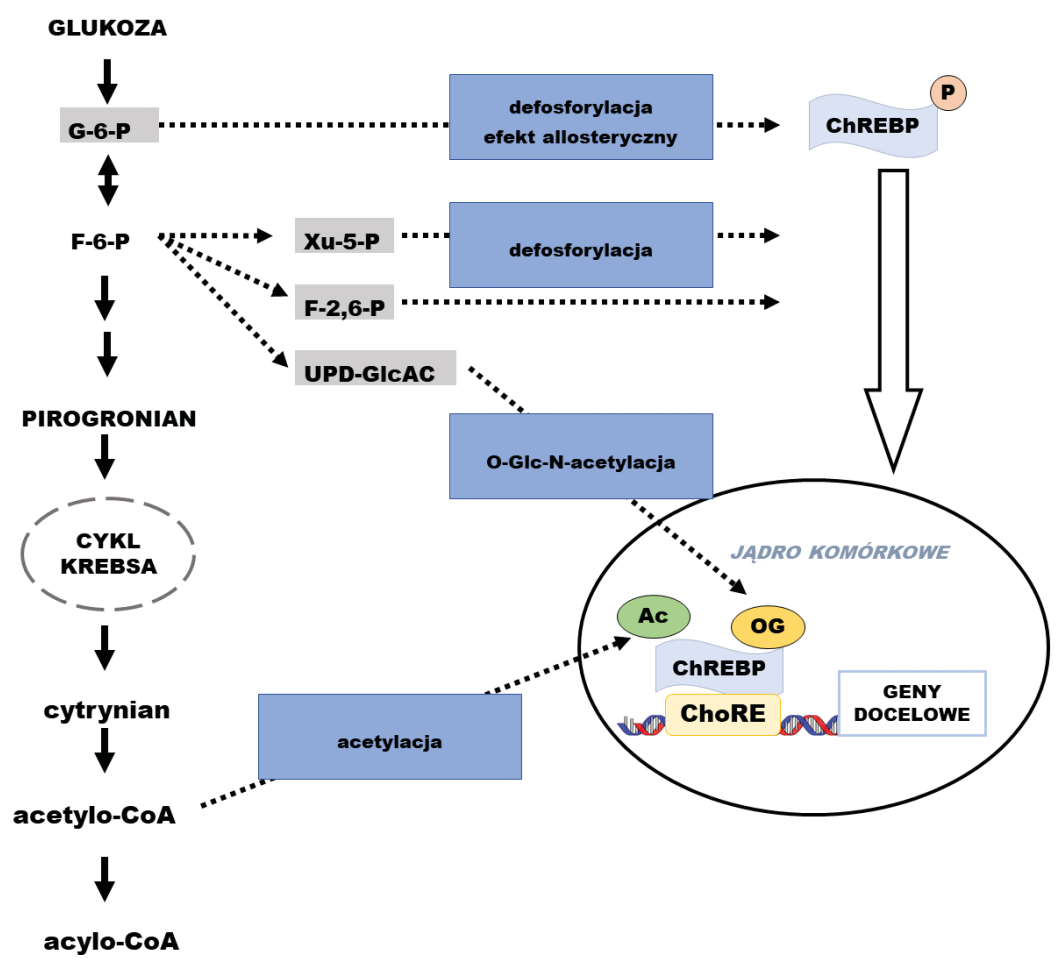

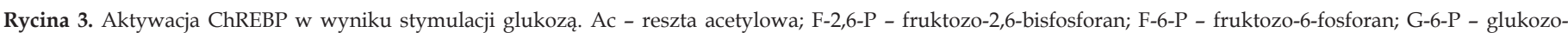

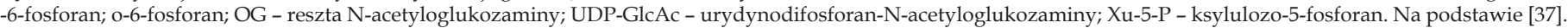


stanie głodu, towarzyszy temu wzrost stężenia ciał ketonowych i AMP [26]. AMP wiąże się bezpośrednio do N-końca białka i poprzez oddziaływanie allosteryczne promuje powstawanie kompleksu ChREBP z białkami 14-3-3, co hamuje import ChREBP do jądra [27]. Ciała ketonowe: $\beta$-hydroksymaślan i acetylooctan, podobnie jak AMP, aktywują i stabilizują kompleks ChREBP z białkami 14-3-3, uniemożliwiając transport do jądra [28]. Wysoka dostępność glukozy promuje ekspresję ChREBP, jego translokację do jądra i wiązanie się do promotorów genów docelowych [29]. Po stymulacji glukozą, fosfataza białkowa 2A (PP2A) defosforyluje ChREBP-a, który następnie może być importowany do jądra [9].

W aktywacji ChREBP istotną rolę odgrywają także pochodne glukozy. Uważa się, że ksylulozo-5-fosforan (Xu-5-P), glukozo-6-fosforan (G-6-P) i fruktozo-2,6-bisfosforan (F-2,6-P) pobudzają aktywność transkrypcyjną ChREBP. Ksylulozo-5-fosforan, metabolit szlaku pentozofosforanowego, aktywuje fosfatazę białkową 2A (PP2A), co prowadzi do defosforylacji białka na Ser196 i Thr666, skutkując jego translokacją do jądra i aktywacją [30]. Glukozo-6-fosforan, produkt reakcji katalizowanej przez heksokinazę, poza aktywacją ChREBP poprzez defosforylację, reguluje go allosterycznie poprzez bezpośrednie wiązanie się do motywu rozpoznającego G-6-P w domenie GRACE [17,31,32]. Fruktozo-2,6-bisfosforan uczestniczy w wiązaniu ChREBP do promotorów glukozo-6-fosfatazy i kinazy pirogronianowej, promując ich ekspresję [33].

Ponadto, w wysokim stężeniu glukozy ChREBP jest poddawany dwóm istotnym modyfikacjom potranslacyjnym odbywającym się na terenie jądra komórkowego: O-Glc-N-acylacji i acetylacji. O-Glc-N-acylacja jest odwracalną modyfikacją potranslacyjną, która zależy od stężenia glukozy i ostatecznego produktu szlaku biosyntezy heksozamin - urydynodifosforanu-N-acetyloglukozaminy (UDP-Glc-N-Ac) [34]. W procesie O-Glc-N-acylacji biorą udział dwa enzymy: transferaza O-Glc-N-Ac (OGT), która katalizuje przyłączenie reszt N-acetyloglukozaminy wiązaniem O-glikozydowym do grupy hydroksylowej seryny lub treoniny danego białka, oraz $\beta$-N-acetylo-D-glukozaminidaza (OGA), która hydrolizuje to wiązanie, usuwając reszty $\mathrm{N}$-acetyloglukozaminy [35]. O-Glc-N-acylacja stabilizuje, wzmacnia aktywność transkrypcyjną i wiązanie się ChREBP do motywów ChoRE docelowych genów glikolitycznych (kinazy pirogronianowej) i lipogenicznych (karboksylazy acetylo-CoA, syntazy kwasów tłuszczowych) w wątrobie w warunkach hiperglikemii [8].

Acetylacja ChREBP polega na przyłączeniu grupy acetylowej do reszty lizyny w pozycji 672 (Lys672), zlokalizowanej w obrębie domeny bHLH/LZ. Reakcja ta katalizowana jest przez, wykazujący aktywność acetylotransferazy histonowej, koaktywator transkrypcyjny CBP/p300. Aktywowany przez glukozę p300 acetyluje ChREBP na Lys672 i zwiększa jego aktywność transkrypcyjną, wzmacniając wiązanie się do promotorów genów docelowych. Mutacja Lys672 znacząco zmniejsza poziom acetylacji ChREBP i osłabia jego aktywację przez glukozę w hepatocytach [36].

\section{FUNKCJE ChREBP}

Celem sprawdzenia, jaka jest fizjologiczna rola ChREBP in vivo, zastosowano mysi model z nokautem genu Chrebp [4]. Zauważono, że myszy Chrebp -/-, karmione standardową dietą dla gryzoni, mają powiększone i przeładowane glikogenem wątroby, wykazują mniejszą zawartość tkanki tłuszczowej i zmniejszone stężenie wolnych kwasów tłuszczowych w osoczu, w porównaniu do grupy kontrolnej. Zwierzęta te przejawiają nie tylko obniżone tempo glikolizy, co skutkuje zmniejszoną produkcją acetylo-CoA do syntezy lipidów, ale także zmniejszoną ekspresję enzymów lipogenicznych; w efekcie następuje u nich obniżenie tempa syntezy triacylogliceroli o $65 \%$. Wysunięto hipotezę, że ChREBP jest odpowiedzialny za koordynację metabolizmu glukozy i kwasów tłuszczowych, co potwierdziły kolejne badania, w których odkryto mechanizm działania tego czynnika i zidentyfikowano geny przez niego regulowane [3].

Podstawową funkcją ChREBP jest promowanie transkrypcji genów związanych z glikolizą. Ekspresji ulega gen transportera glukozy-2 (Glut2), który w warunkach wysokiego stężenia cukru, powoduje jego wnikanie do wnętrza komórek wątroby [3,38]. Następuje również transkrypcja genu kinazy pirogronianowej (Pklr) - powstały enzym katalizuje reakcję transfosforylacji fosfoenolopirogronianu do pirogronianu $\mathrm{z}$ wytworzeniem ATP, co zwiększa szybkość wytwarzania substratu do lipogenezy de novo [5]. ChREBP stymuluje także transkrypcję genów kodujących enzymy szlaku pentozofosforanowego: dehydrogenazy glukozo-6-fosforanowej (G6pdh) i transketolazy $(T k t)$, które dostarczają siłę redukcyjną $\mathrm{w}$ postaci NADPH, niezbędną do syntezy kwasów tłuszczowych. Co więcej, ChREBP reguluje ekspresję genów kodujących enzymy lipogenezy: syntazę kwasów tłuszczowych (Fasn) [39], karboksylazę acetylo-CoA (Acc), liazę cytrynianową ATP (Acyl) i desaturazę stearoilo-CoA 1 (Scd1) [4,11]. Ponadto, czynnik ChREBP aktywuje geny związane z glukoneogenezą - kodujące: podjednostkę katalityczną glukozo-6-fosfatazy (G6pc), fruktozo-1,6-bisfosfatazę 1 (Fbp1) oraz receptory glukagonu (Gcgr) [40], a także czynniki transkrypcyjne warunkujące rytm okołodobowy (Dec1, Klf10) [3,41]. Na rycinie 4 podsumowano działanie ChREBP jako regulatora ekspresji genów kodujących enzymy różnych szlaków metabolicznych w wątrobie. Jak już poprzednio wspomniano, genem docelowym dla ChREBP jest również Chrebp $\beta$ [9].

Najwyższą zawartość białka ChREBP stwierdzono w wątrobie, gdzie główną jego rolą jest regulowanie lipogenezy de novo. Badanie przeprowadzone na myszach z nokautem genu Chrebp wykazało, że aktywność wątrobowej lipogenezy jest $\mathrm{u}$ nich obniżona o połowę. Myszy takie, żywione standardową dietą, mają umiarkowaną nietolerancję glukozy i insulinooporność, w porównaniu do grupy kontrolnej [5]. Co więcej, wątroby myszy Chrebp -/ - są w stanie hipoenergetycznym, co spowodowane jest niemal całkowitym zahamowaniem metabolizmu, z wyjątkiem oksydacji pirogronianu, która jest wzmożona [42]. 


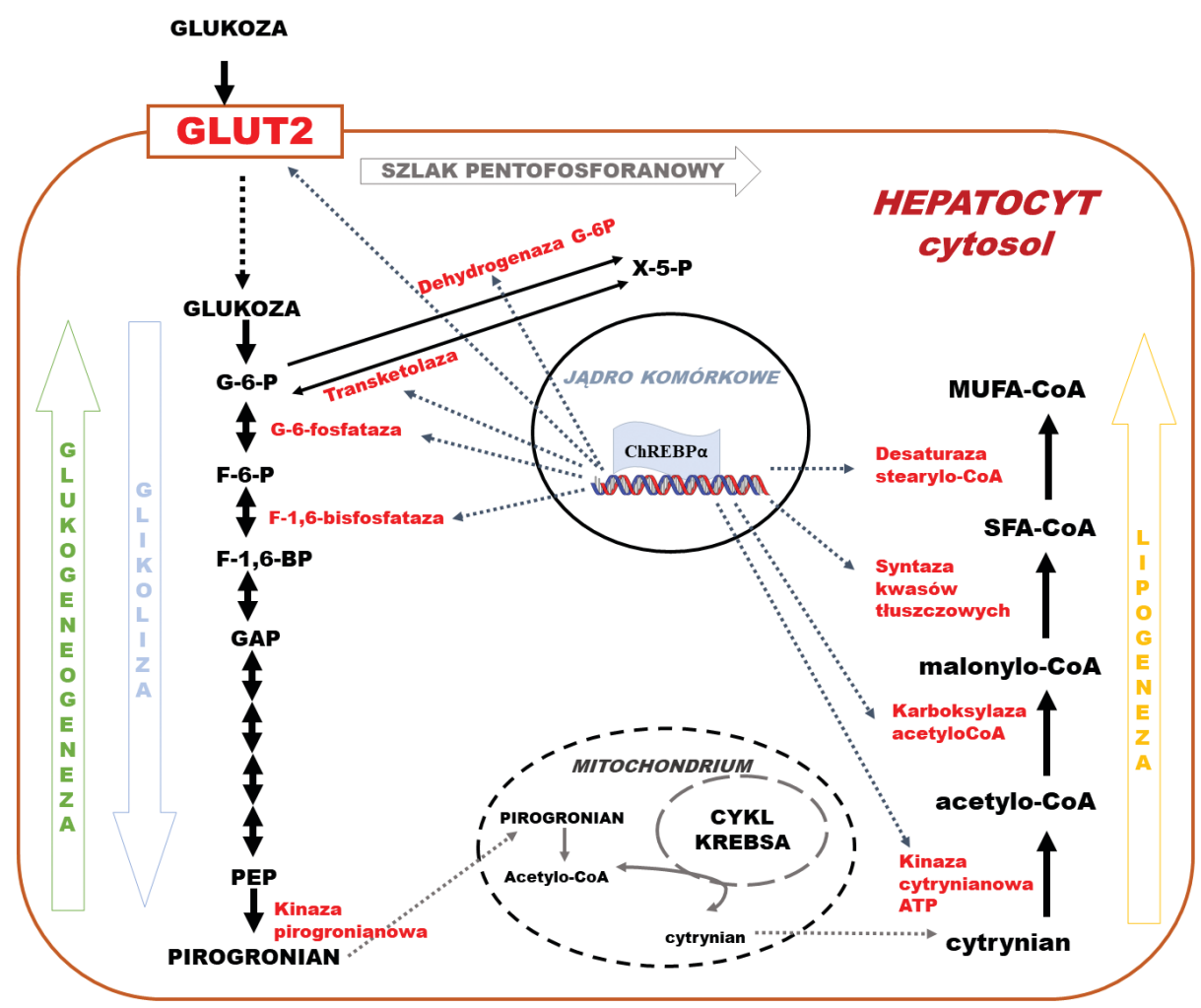

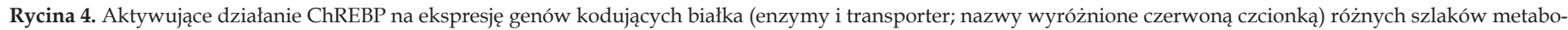

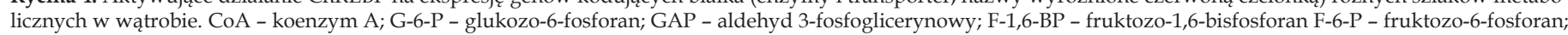
MUFA - nienasycone kwasy tłuszczowe; PEP - fosfoenolopirogronian; SFA - nasycone kwasy tłuszczowe; X-5-P - ksylulozo-5-fosforan. Na podstawie [29].

Nadekspresja genu kodującego ChREBP u myszy, żywionych dietą zarówno standardową jak i wysokotłuszczową, prowadzi do rozwoju zespołu metabolicznego i stłuszczenia wątroby. W takich warunkach intensywniej zachodzą glukoneogeneza i lipogeneza de novo. Jednak, odwrotnie niż w przypadku delecji genu, zaobserwowano wzrost wrażliwości na insulinę i ogólny pozytywny wpływ na metabolizm cukrów i tłuszczy, co pozwala rozgraniczyć stłuszczenie wątroby od insulinooporności [43]. Wzrost poziomu ChREBP zwiększa ekspresję desaturazy stearoilo-CoA, która przekształca nasycone kwasy tłuszczowe (SFA) w jednonienasycone kwasy tłuszczowe (MUFA). Ponieważ SFA mogą zakłócać sygnalizację insulinową, zasugerowano, że to właśnie zmiana stosunku SFA do MUFA zapobiega rozwojowi insulinooporności [43].

Gen kodujący ChREBP ulega intensywnej ekspresji w mysiej, szczurzej i ludzkiej brunatnej i białej tkance tłuszczowej [9]. Lipogeneza de novo w białej tkance tłuszczowej zachodzi dużo mniej aktywnie niż $\mathrm{w}$ wątrobie, co zasugerowało inne funkcje ChREBP w tej tkance [44]. Rolę ChREBP zbadano u myszy z nadekspresją ChREBP-CA (konstytutywnie aktywny ChREBP), które żywiono dietą odpowiadającą diecie zachodniej (wysokokaloryczna, bogata w cukry, tłuszcze nasycone i produkty wysoko przetworzone). Zauważono poprawę wrażliwości na insulinę oraz zmniejszenie stłuszczenia wątroby i ogólnej masy tłuszczu. Ponadto odkryto, że czynnik ChREBP reguluje geny związane $\mathrm{z}$ różnicowaniem i transformacją bia- łych komórek tłuszczowych w brunatne, metabolizmem lipidów oraz stanem zapalnym [22]. W brunatnej tkance tłuszczowej poziom lipogenezy jest dużo wyższy niż w białej. Myszy całkowicie pozbawione czynnika ChREBP wykazują zmniejszoną masę brunatnej tkanki tłuszczowej, stają się hipotermiczne, gdy są żywione dietą bogatą w węglowodany, i wykazują łagodną hipotermię, gdy są żywione dietą bogatą $\mathrm{w}$ tłuszcze [5]. ChREBP bierze zatem udział w regulacji termogenezy [23].

Stwierdzono, że ChREBP ulega ekspresji w ludzkiej, szczurzej i mysiej trzustce, gdzie stymulowany glukozą aktywuje transkrypcję genów docelowych. Ponadto czynnik ChREBP jest niezbędny do pobudzanej glukozą proliferacji komórek $\beta$ in vitro i in vivo - supresja ChREBP znacząco ogranicza ten proces [45]. Aktywacja ChREBP prowadzi również do wzmożonego różnicowania komórek $\beta \mathrm{w}$ szczurzej trzustce, a jego poziom rośnie wraz $\mathrm{z}$ postępującym różnicowaniem [46].

\section{ROLA ChREBP W STANACH PATOLOGICZNYCH}

Insulinooporność jest stanem obniżonej odpowiedzi biologicznej tkanek, w tym szczególnie wątroby, na działanie insuliny. Insulinooporność indukuje występowanie różnych zaburzeń metabolicznych i chorób. W wyniku nieprawidłowej sygnalizacji insulinowej i dostarczania nadwyżek energii z pokarmem następuje m.in. nasilenie syntezy kwasów tłuszczowych de novo w wątrobie i akumulacja triacylogliceroli w jej komórkach. Prowadzi to do niealkoholowego stłuszczenia wątroby (NAFLD), które 
jest najczęstszą przyczyną przewlekłej choroby tego narządu; szacuje się, że w Stanach Zjednoczonych dotyczy od 80 do 100 milionów osób, czyli co czwartego obywatela [47].

Badania na wątrobach pacjentów z NAFLD wykazały, że ekspresja genu kodującego ChREBP jest pozytywnie skorelowana ze stopniem stłuszczenia i stężeniem enzymów lipogenicznych, a negatywnie z insulinoopornością, mimo występowania wyraźnego związku między tymi chorobami. Potwierdziły to badania na myszach $\mathrm{z}$ nadekspresją genu Chrebp, które pozostały wrażliwe na insulinę, mimo wzmożonej lipogenezy i stłuszczenia wątroby [43]. Inhibicja ChREBP zapobiega rozwojowi stłuszczenia wątroby i otyłości (jeśli są one zależne od diety), co potwierdziło doświadczenie na myszach, którym usunięto gen Chrebp. Myszy te, gdy żywiono je dietą w 60\% złożoną ze skrobi, wykazywały zmniejszoną zawartość triacylogliceroli $\mathrm{w}$ wątrobie oraz mniejszą masę ciała niż zwierzęta kontrolne [3]. Biorąc pod uwagę fakt, że supresja ChREBP skutecznie zapobiega stłuszczeniu wątroby wywołanym dietą bogatą w weglowodany, Iizuka zaproponował połączenie diety leczniczej i podawania aktywatorów negatywnych regulatorów ChREBP jako korzystne działanie w leczeniu NAFLD [48].

Przewlekła hiperglikemia, charakterystyczna dla cukrzycy typu 2, przyczynia się do zaburzenia funkcjonowania komórek $\beta$ trzustki. W wyspach trzustkowych pacjentów z rozwiniętą chorobą stwierdzono wzmożoną ekspresję genu ChREBP oraz zwiększoną translokację tego czynnika do jądra. Ponadto, zauważono podwyższony poziom ekspresji genów docelowych ChREBP. Co ciekawe, u mysich modeli cukrzycy typu 2 wykazano wzrost ekspresji Chrebp $\beta$ w wyspach trzustkowych, skorelowany ze spadkiem ekspresji Chrebpa, potwierdzając tym samym istnienie wzajemnej zależności między tymi izoformami. Nadekspresja ChREBP-CA w trzustce myszy spowodowała wystąpienie wszelkich objawów dysfunkcji komórek $\beta$, takich jak zmniejszenie wydzielania insuliny, stres oksydacyjny i apoptoza, co wydaje się dowodzić istotnej roli ChREBP w patogenezie cukrzycy [23]. Należy jednak zauważyć, że ChREBP jest niezbędny do pobudzanej glukozą proliferacji komórek $\beta$, a do zaburzeń przyczynia się $\mathrm{w}$ warunkach stałego przeładowania energetycznego, gdy jest nadmiernie aktywny. Cukrzyca typu 2 dotyka ponad 380 milionów ludzi na świecie, szczególnie ważne jest zatem dogłębne zrozumienie jej molekularnego podłoża, a dokładne wyjaśnienie mechanizmów odpowiedzialnych za regulację ekspresji i aktywności ChREBP może pozwolić na wskazanie kolejnego obiecującego celu terapeutycznego [49].

Komórki nowotworowe charakteryzuje produkcja dużych ilości mleczanu w warunkach tlenowych. Jest to tzw. efekt Warburga, zwany również glikolizą tlenową. Ponadto, komórki te szybko profilerują, przez co mają także zwiększone tempo syntezy kwasów tłuszczowych. Supresja ChREBP w komórkach raka jelita grubego powoduje przejście metaboliczne z glikolizy tlenowej do fosforylacji oksydacyjnej oraz zmniejszenie syntezy kwasów tłuszczowych i nukleotydów; skutkuje również akty- wacją p53 i zatrzymaniem cyklu komórkowego. Twierdzi się zatem, że ChREBP odgrywa kluczową rolę w inhibicji białka p53, glikolizie tlenowej i anabolizmie komórek nowotworowych [50]. Związek między zwiększoną ilością i aktywnością ChREBP a proliferacją komórek nowotworowych obserwuje się także w przypadku raka piersi, płuc, wątroby, prostaty, trzustki i pęcherza moczowego. lizuka zauważył, że inhibicja ChREBP mogłaby zapobiegać proliferacji komórek nowotworowych [48] i jako taka zostać wykorzystana jako narzędzie w terapii przeciwnowotworowej.

\section{PODSUMOWANIE}

ChREBP, jako czynnik transkrypcyjny regulujący metabolizm energetyczny, pełni istotne funkcje zarówno w warunkach fizjologicznych, jak i patofizjologicznych. Odgrywa ważną rolę w adaptacji organizmu do zmian stanu odżywienia, w tym do zmian dostępności glukozy. Stymulowany sygnałami sytości, aktywuje transkrypcję genów glikolitycznych i lipogenicznych, prowadząc do tworzenia zapasów energii w postaci tłuszczu. Nadmierna podaż pokarmów skutkuje zwiększoną aktywnością ChREBP, a w konsekwencji rozregulowaniem metabolizmu glukozy i lipidów. Zaburzenia w homeostazie energetycznej mogą prowadzić do występowania chorób metabolicznych, na przykład stłuszczenia wątroby, dlatego odkrycie dokładnych zależności między ChREBP a patogenezą może okazać się istotne we wczesnym ich diagnozowaniu i opracowaniu nowych form i celów terapii.

\section{PIŚMIENNICTWO}

1. Yamashita H, Takenoshita M, Sakurai M, Bruick R, Henzel W, Shillinglaw W, Arnot D, Uyeda K (2001) A glucose-responsive transcription factor that regulates carbohydrate metabolism in the liver. Proc Natl Acad Sci U S A 98: 9116-21

2. Luis O de, Valero M, Jurado L (2000) WBSCR14, a putative transcription factor gene deleted in Williams-Beuren syndrome: complete characterisation of the human gene and the mouse ortholog. Eur J Hum Genet 8: 215-22

3. Iizuka K, Miller B, Uyeda K (2006) Deficiency of carbohydrate-activated transcription factor ChREBP prevents obesity and improves plasma glucose control in leptin-deficient (ob/ob) mice. Am J Physiol Endocrinol Metab 291: E358-64

4. Iizuka K, Bruick R, Liang G, Horton J, Uyeda K (2004) Deficiency of carbohydrate response element-binding protein (ChREBP) reduces lipogenesis as well as glycolysis. Proc Natl Acad Sci U S A 101: 7281-6

5. Poungvarin N, Lee J, Yechoor V, Li M, Assavapokee T, Suksaranjit $\mathrm{P}$, Thepsongwajja J, Saha P, Oka K, Chan L (2012) Carbohydrate response element-binding protein (ChREBP) plays a pivotal role in beta cell glucotoxicity. Diabetologia 55: 1783-96

6. Stoeckman A, Ma L, Towle H (2004) Mlx is the functional heteromeric partner of the carbohydrate response element-binding protein in glucose regulation of lipogenic enzyme genes. J Biol Chem 279: 15662-9

7. Ortega-Prieto P, Postic C (2019) Carbohydrate sensing through the transcription factor ChREBP. Front Genet 10: 472

8. Guinez C, Filhoulaud G, Rayah-Benhamed F, Marmier S, Dubuquoy C, Dentin R, Moldes M, Burnol A-F, Yang X, Lefebvre T, Girard J, Postic C (2011) O-GlcNAcylation increases ChREBP protein content and transcriptional activity in the liver. Diabetes 60: 1399-413

9. Herman M, Peroni O, Villoria J, Schön M, Abumrad N, Blüher M, Klein S, Kahn B (2012) A novel ChREBP isoform in adipose tissue regulates systemic glucose metabolism. Nature 484: 333-8 
10. Filhoulaud G, Guilmeau S, Dentin R, Girard J, Postic C (2013) Novel insights into ChREBP regulation and function. Trends Endocrinol Metab 24: 257-68

11. lizuka K, Horikawa Y (2008) ChREBP: a glucose-activated transcription factor involved in the development of metabolic syndrome. Endocr J 55: 617-24

12. Sakiyama H, Wynn R, Lee W-R, Fukasawa M, Mizuguchi H, Gardner K, Repa J, Uyeda K (2008) Regulation of nuclear import/export of carbohydrate response element-binding protein (ChREBP): interaction of an alpha-helix of ChREBP with the 14-3-3 proteins and regulation by phosphorylation. J Biol Chem 283: 24899-908

13. Ge Q, Nakagawa T, Wynn R, Chook Y, Miller B, Uyeda K (2011) Importin-alpha protein binding to a nuclear localization signal of carbohydrate response element-binding protein (ChREBP). J Biol Chem 286: 28119-27

14. Li M, Chang B, Imamura M, Poungvarin N, Chan L (2006) Glucose-dependent transcriptional regulation by an evolutionarily conserved glucose-sensing module. Diabetes 55: 1179-89

15. Singh P, Irwin D (2016) Contrasting patterns in the evolution of vertebrate MLX interacting protein (MLXIP) and MLX interacting protein-like (MLXIPL) genes. PLoS ONE 11: e0149682

16. Davies M, O'Callaghan B, Towle H (2008) Glucose activates ChREBP by increasing its rate of nuclear entry and relieving repression of its transcriptional activity. J Biol Chem 283: 24029-38

17. McFerrin L, Atchley W (2012) A novel N-terminal domain may dictate the glucose response of Mondo proteins. PLoS ONE 7: e34803

18. Zhang P, Kumar A, Katz L, Li L, Paulynice M, Herman M, Scott D (2015) Induction of the ChREBP $\beta$ isoform is essential for glucose-stimulated $\beta$-cell proliferation. Diabetes 64: 4158-70

19. Ge Q, Huang N, Wynn R, Li Y, Du X, Miller B, Zhang H, Uyeda K (2012) Structural characterization of a unique interface between carbohydrate response element-binding protein (ChREBP) and 14-3-3 $\beta$ Protein. J Biol Chem 287: 41914-21

20. Montagner A, Korecka A, Polizzi A, Lippi Y, Blum Y, Canlet C, Tremblay-Franco M, Gautier-Stein A, Burcelin R, Yen Y-C, Je H, Al-Asmakh M, Maha A-A, Mithieux G, Arulampalam V, Lagarrigue S et al. (2016) Hepatic circadian clock oscillators and nuclear receptors integrate microbiome-derived signals. Sci Rep 6: 20127

21. Jing G, Chen J, Xu G, Shalev A (2016) Islet ChREBP- $\beta$ is increased in diabetes and controls ChREBP- $\alpha$ and glucose-induced gene expression via a negative feedback loop. Mol Metab 5: 1208-15

22. Nuotio-Antar A, Poungvarin N, Li M, Schupp M, Mohammad M, Gerard S, Zou F, Chan L (2015) FABP4-Cre mediated expression of constitutively active ChREBP protects against obesity, fatty liver, and insulin resistance. Endocrinology 156: 4020-32

23. Abdul-Wahed A, Guilmeau S, Postic C (2017) Sweet sixteenth for ChREBP: Established roles and future goals. Cell Metab 26: 324-41

24. Kawaguchi T, Takenoshita M, Kabashima T, Uyeda K (2001) Glucose and cAMP regulate the L-type pyruvate kinase gene by phosphorylation/dephosphorylation of the carbohydrate response element binding protein. Proc Natl Acad Sci U S A 98: 13710-5

25. Kawaguchi T, Osatomi K, Yamashita H, Kabashima T, Uyeda K (2002) Mechanism for fatty acid "sparing" effect on glucose-induced transcription: regulation of carbohydrate-responsive element-binding protein by AMP-activated protein kinase. J Biol Chem 277: 3829-35

26. Newman J, Verdin E (2014) Ketone bodies as signaling metabolites. Trends Endocrinol Metab 25: 42-52

27. Sato S, Jung H, Nakagawa T, Pawlosky R, Takeshima T, Lee W-R, Sakiyama H, Laxman S, Wynn R, Tu B, MacMillan J, Brabander J de, Veech $\mathrm{R}$, Uyeda $\mathrm{K}$ et al. (2016) Metabolite regulation of nuclear localization of carbohydrate-response element-binding protein (ChREBP): role of AMP as an allosteric inhibitor. J Biol Chem 291: 10515-27

28. Nakagawa T, Ge Q, Pawlosky R, Wynn R, Veech R, Uyeda K (2013) Metabolite regulation of nucleo-cytosolic trafficking of carbohydrate response element-binding protein (ChREBP): role of ketone bodies. J Biol Chem 288: 28358-67
29. Uyeda K, Repa J (2006) Carbohydrate response element binding protein, ChREBP, a transcription factor coupling hepatic glucose utilization and lipid synthesis. Cell Metab 4: 107-10

30. Kabashima T, Kawaguchi T, Wadzinski B, Uyeda K (2003) Xylulose 5-phosphate mediates glucose-induced lipogenesis by xylulose 5-phosphate-activated protein phosphatase in rat liver. Proc Natl Acad Sci US A 100: 5107-12

31. Dentin R, Tomas-Cobos L, Foufelle F, Leopold J, Girard J, Postic C, Ferré P (2012) Glucose 6-phosphate, rather than xylulose 5-phosphate, is required for the activation of ChREBP in response to glucose in the liver. J Hepatol 56: 199-209

32. Li M, Chen W, Harmancey R, Nuotio-Antar A, Imamura M, Saha P, Taegtmeyer H, Chan L (2010) Glucose-6-phosphate mediates activation of the carbohydrate responsive binding protein (ChREBP). Biochem Biophys Res Commun 395: 395-400

33. Arden C, Tudhope S, Petrie J, Al-Oanzi Z, Cullen K, Lange A, Towle H, Agius L (2012) Fructose 2,6-bisphosphate is essential for glucose-regulated gene transcription of glucose-6-phosphatase and other ChREBP target genes in hepatocytes. Biochem J 443: 111-23

34. Issad T, Kuo M (2008) O-GlcNAc modification of transcription factors, glucose sensing and glucotoxicity. Trends Endocrinol Metab 19: 380-9

35. Zeidan Q, Hart G (2010) The intersections between O-GlcNAcylation and phosphorylation: implications for multiple signaling pathways. J Cell Sci 123: 13-22

36. Bricambert J, Miranda J, Benhamed F, Girard J, Postic C, Dentin R (2010) Salt-inducible kinase 2 links transcriptional coactivator p300 phosphorylation to the prevention of ChREBP-dependent hepatic steatosis in mice. J Clin Invest 120: 4316-31

37. lizuka K (2017) The transcription factor carbohydrate-response element-binding protein (ChREBP): A possible link between metabolic disease and cancer. Biochim Biophys Acta Mol Basis Dis 1863: 474-85

38. Uldry M, Ibberson M, Hosokawa M, Thorens B (2002) GLUT2 is a high affinity glucosamine transporter. FEBS Letters 524: 199-203

39. Ma L, Robinson L, Towle H (2006) ChREBP*Mlx is the principal mediator of glucose-induced gene expression in the liver. J Biol Chem 281 28721-30

40. Kim M-S, Krawczyk S, Doridot L, Fowler A, Wang J, Trauger S, Noh H-L, Kang H, Meissen J, Blatnik M, Kim J, Lai M, Herman M (2016) ChREBP regulates fructose-induced glucose production independently of insulin signaling. J Clin Invest 126: 4372-86

41. Iizuka K, Takeda J, Horikawa Y (2011) Krüppel-like factor-10 is directly regulated by carbohydrate response element-binding protein in rat primary hepatocytes. Biochem Biophys Res Commun 412: 638-43

42. Burgess S, lizuka K, Jeoung N, Harris R, Kashiwaya Y, Veech R, Kitazume T, Uyeda K (2008) Carbohydrate-response element-binding protein deletion alters substrate utilization producing an energy-deficient liver. J Biol Chem 283: 1670-8

43. Benhamed F, Denechaud P-D, Lemoine M, Robichon C, Moldes M, Bertrand-Michel J, Ratziu V, Serfaty L, Housset C, Capeau J, Girard J, Guillou H, Postic C (2012) The lipogenic transcription factor ChREBP dissociates hepatic steatosis from insulin resistance in mice and humans. J Clin Invest 122: 2176-94

44. Kursawe R, Caprio S, Giannini C, Narayan D, Lin A, D'Adamo E, Shaw M, Pierpont B, Cushman S, Shulman G (2013) Decreased transcription of ChREBP- $\alpha / \beta$ isoforms in abdominal subcutaneous adipose tissue of obese adolescents with prediabetes or early type 2 diabetes: associations with insulin resistance and hyperglycemia. Diabetes 62: 837-44

45. Metukuri M, Zhang P, Basantani M, Chin C, Stamateris R, Alonso L, Takane K, Gramignoli R, Strom S, O'Doherty R, Stewart A, Vasavada R, Garcia-Ocaña A, Scott D et al. (2012) ChREBP mediates glucose-stimulated pancreatic $\beta$-cell proliferation. Diabetes 61: 2004-15

46. Soggia A, Flosseau K, Ravassard P, Szinnai G, Scharfmann R, Guillemain G (2012) Activation of the transcription factor carbohydrate-responsive element-binding protein by glucose leads to increased pancreatic beta cell differentiation in rats. Diabetologia 55: 2713-22

47. Perumpail B, Khan M, Yoo E, Cholankeril G, Kim D, Ahmed A (2017) Clinical epidemiology and disease burden of nonalcoholic fatty liver disease. World J Gastroenterol 23: 8263-76 
48. Watson RR., Preedy VR. (2019) Dietary Interventions in Liver Disease, Foods, Nutrients and Dietary Supplements, San Diego: Elsevier Science \& Technology

49. Song Z, Yang H, Zhou L, Yang F (2019) Glucose-sensing transcription factor MondoA/ChREBP as targets for type 2 diabetes: opportunities and challenges. Int J Mol Sci 20 pii: E5132
50. Tong X, Zhao F, Mancuso A, Gruber J, Thompson C (2009) The glucose-responsive transcription factor ChREBP contributes to glucose-dependent anabolic synthesis and cell proliferation. Proc Natl Acad Sci U S A 106: 21660-5

\section{Transcription factor ChREBP - the coordinator of carbohydrate and lipid metabolism}

\section{Joanna Krawczak, Aleksandra Owczarek, Katarzyna Winiarska ${ }^{\varpi}$}

Department of Metabolic Regulation, Institute of Biochemistry, Faculty of Biology, University of Warsaw

${ }^{\bowtie}$ Corresponding author: k.winiarska@biol.uw.edu.pl

Keywords: ChREBP, transcription factor, carbohydrate metabolism, lipid metabolism, metabolic disease

\section{SUMMARY}

Transcription factor ChREBP, in complex with MLX, binds to carbohydrate-response element (ChoRE) located in the promoters of genes related to glycolysis, gluconeogenesis, pentosephosphate pathway and lipogenesis, activating their transcription following stimulation with glucose, insulin-independently. In this article the mechanisms of ChREBP regulation and ChREBP functions under both physiological and pathophysiological conditions are described in detail. The possible use of ChREBP activity modulation as a therapeutic tool, e.g. in case of nonalcoholic fatty liver disease, diabetes type 2 and cancers, is also discussed. 